\title{
Ultrastructural Identification of Circovirus in the Liver of Saffron Finch (Sicalis flaveola spp.)
}

\author{
Identificación Ultrastructural de circovirus en el \\ Hígado de Canarios Venezolanos (Sicalis flaveola spp.)
}

\author{
"Catroxo, M. H. B.; "Martins, A. M. C. R. P. F.; "Melo, N. A.; "*Milanelo, L.; ${ }^{* * *}$ Petrella, S.; **Fitorra, L. S. \& *** Petri, B. S. S.
}

CATrOXO, M. H. B.; MARTINS, A. M .C. R. P. F.; MELO, N. A. ; MILANELO, L. ; PETRELLA, S.; FITORRA, L. S. \& PETRI, B. S. S. Ultrastructural identification of circovirus in the liver of saffron finch (Sicalis flaveola spp.). Int. J. Morphol., 29(2):537$542,2011$.

SUMMARY: Circovirus are viral agents that cause disease in avian species. The main clinical symptoms of the disease are immunosuppression and, in young birds feather disorders. In neonates, the disease is known as "black spot" and characterized by abdominal enlargement, hepatobiliar congestion and failure to thrive. Also, it was observed in adult infected birds with other symptoms and clinical signs, such as enteritis, sinusitis, rhinitis, tracheitis, bronchopneumonia, myocarditis, nephritis, splenitis, dyspnea, anorexia, depression leading to high mortality. In April 2008, 317 saffron finch were apprehended during an illegal commercialization and were forwarded to the Wild Animals Recovery Center of the Tiete Ecological Park. Subsequently, 101 (31.66\%) died and 20 of these were selected and sent to the Laboratory of Electron Microscopy, Biological Institute of São Paulo, Brazil to investigate possible etiological agents. After necropsy of these animals fragments of lung, liver and small intestine were processed using negative staining and resin embedding techniques. On the transmission electron microscopy, the negative staining technique allowed observation in 20 (100\%) samples of liver suspension, a great number of particles with morphology similar to the circovirus, spherical, non-enveloped, isometric, characterized as "complete" and "empty ", measuring between 17 and $20 \mathrm{~nm}$ in diameter. By the resin embedding technique, oval or rounded viral intracytoplasmatic inclusion bodies, containing viral particles disposed in paracrystalline arrays or loose arrangements were observed in ultrathin sections on the $20(100 \%)$ samples of liver suspension. This is the first report on the presence of circovirus in saffron finch (Sicalis flaveola spp.).

KEY WORDS: Avian circovirus; Canaries; Sicalis flaveola spp.

\section{INTRODUCTION}

Circovirus are viral agents that cause disease in avian (Raue et al., 2005) and swine species (Allan \& Ellis, 2000). In avian species the main clinical symptoms are immunosuppression and, in young birds feather disorders (Raue et al.).

Several other symptoms, caused by immunosuppression and triggered by secondary bacterial, fungal or chlamydial infections such as enteritis, sinusitis, rhinitis, tracheitis, bronchopneumonia, myocarditis, nephritis, splenitis, dyspnea, anorexia, with a high mortality rate (Goldsmith, 1995; Rampin et al., 2006) have been verified in canaries.

Circovirus in neonates has been long described in European industry of canaries, as the "black spot" and it is characterized by abdominal enlargement, hepatobiliar congestion and failure to thrive (Goldsmith; Rampini et al.). Also, necrosis of epithelial tissue and oral mucosa (Phenix et al., 2001) may occur. Most newborns die within seven days, and the percentage reaches $100 \%$ morbidity and $90 \%$ of mortality (Woods \& Latimer, 2000).

The transmission of this disease is referred to as oral, intranasal and intra-cloacal routes (Ritchie et al., 1991).

The Circoviridae family comprises two genera Gyrovirus and Circovirus. In the latter, the genome is organized in an ambisense direction. The replicationassociated (Rep) protein is encoded from the virus-sense strand (ORF-V1) and the capsid protein from the

* Laboratory of Electron Microscopy, Biological Institute of São Paulo, SP, Brasil.

** Tietê Ecological Park, São Paulo, SP, Brasil.

**** Adolfo Lutz Institute, São Paulo, SP, Brasil. 
complementary sense-strand (ORF-C1) of the genomes of all viruses of the genus Circovirus. Additional small open reading frames (ORFs) are present in some of the circoviruses (Niagro et al., 1998; Johne et al., 2006). The DNA viral genome is circular single-stranded of $2 \mathrm{~kb}$ in size (Todd et al., 2005).

When visualized in preparations on the electron microscope, circovirus present as small, non enveloped, round to icosahedral particles, with a diameter of 15-17 nm (Niagro et al.; Todd et al., 1991).

To date, literature reports the existence of 11 species of circovirus, such as the Beak and feather disease virus of parrots (Bassami et al., 1998; Sanada et al., 1999; Kiatipattanasakul-Banlunara et al., 2002), Pigeon circovirus (Todd et al., 2001), Canary circovirus (Phenix et al.), Goose circovirus (Todd et al., 2001), Duck circovirus (Soike et al., 2004), Finch circovirus and Gull circovirus (Smyth et al. 2006, Todd et al., 2007), Starling circovirus (Johne et al.) and the Swan circovirus (Halami et al., 2008). Also, there are two species in swine, the Porcine circovirus-1, not associated to any type of pathology and the Porcine circovirus-2 that causes multisystemic wasting syndrome (Allan \& Ellis).

The circovirus was also identified in Australian raves (Stewart et al., 2006) and in ostrich (Els \& Josling, 1998).

In canaries from aviaries with a history of high mortality, the circovirus was detected by transmission electron microscopy in organs from poultry farms (Guercio et al., 2000, Todd et al., 2001; Rampin et al.).

Cytoplasmic inclusion bodies can be observed in ultrathin sections of small intestine, skin and bursa of Fabricius (Rampin et al.; Kiatipattanasakul-Banlunara et al.; Todd et al., 2007).

The present study describes the occurrence of circovirus in liver fragments of Saffron finch (Sicalis flaveola spp.), using transmission electron microscopy techniques.

\section{MATERIAL AND METHOD}

Samples. In April 2008, during an illegal commercialization of wild birds 317 Saffron finch (Sicalis flaveola spp) were apprehended and sent to the Center of Recovery of Wild Animals of the Tietê Ecological Park. Of these, 101 (31.66\%) had sudden apathy, ruffled feathers and died. Twenty of these animals were selected and sent to the Laboratory of Electron
Microscopy, Biological Institute of São Paulo, where the necropsy was performed by collecting fragments of lung, liver and small intestine which were processed for transmission electron microscopy, using negative staining (rapid preparation) and resin embedding techniques to search for the etiologic agent.

Negative Staining Technique. In this technique, samples were suspended in $0.1 \mathrm{M}$ phosphate buffer, $\mathrm{pH} 7.0$, placed in contact with metallic copper grids, previously covered with carbon and collodion film, drained with filter paper and negatively stained at $2 \%$ with ammonium molybdate, pH 5.0 (Brenner \& Horne, 1959; Hayat \& Miller, 1990; Madeley, 1997).

Resin Embedding Technique. The samples were fixed in 2\% glutaraldehyde in $0.1 \mathrm{M}$ phosphate buffer, $\mathrm{pH} 7.0$, post fixed in $1 \%$ osmium tetroxide in the same buffer, dehydrated in cetonic series and embedded in Spurr resin (GonzálezSantander, 1969 ; Luft, 1961). Ultrathin sections 70 nm thick were positive stained by the combination of $2 \%$ uranyl acetate (Watson, 1958) and 0.5\% lead citrate (Reynolds, 1963).

All samples were examined and photographed on a transmission electron microscope Philips EM 208, voltage $80 \mathrm{kV}$.

\section{RESULTS}

On the transmission electron microscopy, by the negative staining technique, a large number of particles with morphology similar to the circovirus spherical, nonenveloped, isometric, characterized as "complete" and "empty", measuring between 17 and $20 \mathrm{~nm}$ in diameter, were visualized in suspensions of liver fragments of the 20 (100\%) examined birds (Fig. 1).

Using the resin embedding technique (positive staining) electron-dense viral intracytoplasmic inclusions bodies, rounded or oval, were observed mostly located close to or associated with cell nucleus, measuring 200 to $700 \mathrm{~nm}$ in diameter (fig. 2). They had viral particles from 10 to 14 $\mathrm{nm}$ in diameter (Fig. 3, big arrow) in loose arrangements or in paracrystalline arrays (Fig. 3, minor arrow).

In suspensions of liver fragments, no other pathogen besides circovirus was observed.

When fragments of lungs and intestines were analyzed, the presence of circovirus or other agents was not observed. 


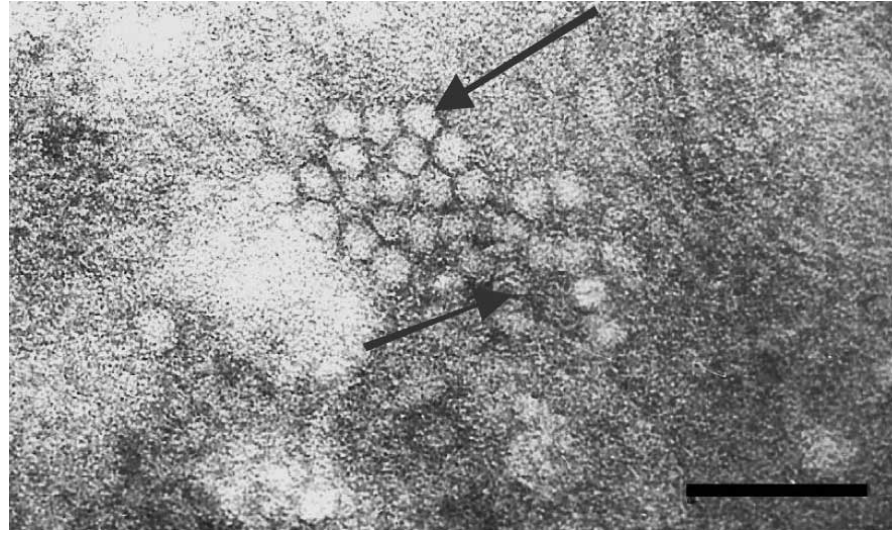

Fig. 1. Negatively stained circovirus particles, non-enveloped, spherical, isometric, characterized as "complete" (big arrow) and "empty". (minor arrow). Bar: $110 \mathrm{~nm}$.

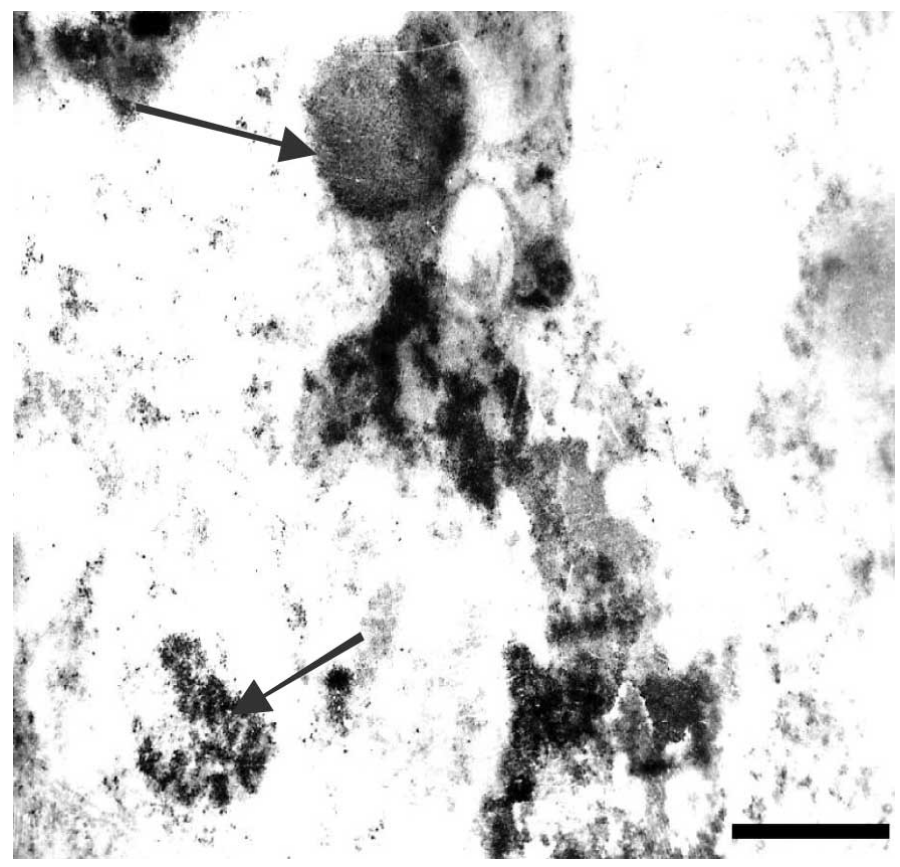

Fig. 3. Ultrathin section of the fragments of liver. Intracytoplasmic viral inclusion bodies, containing circovirus-like particles either in paracrystalline arrays or loose arrangements. Bar: 800nm.

\section{DISCUSSION}

In this study, the observation through the negative staining technique of viral particles with characteristic of circovirus, in suspensions of liver fragments of $20(100 \%)$ Sicalis flaveola spp is in accordance with other reports about canaries showing spherical, non-enveloped particles with a mean diameter of $18 \mathrm{~nm}$ (Guercio et al.; Todd, 2000; Todd et al., 2001; Phenix et al.).

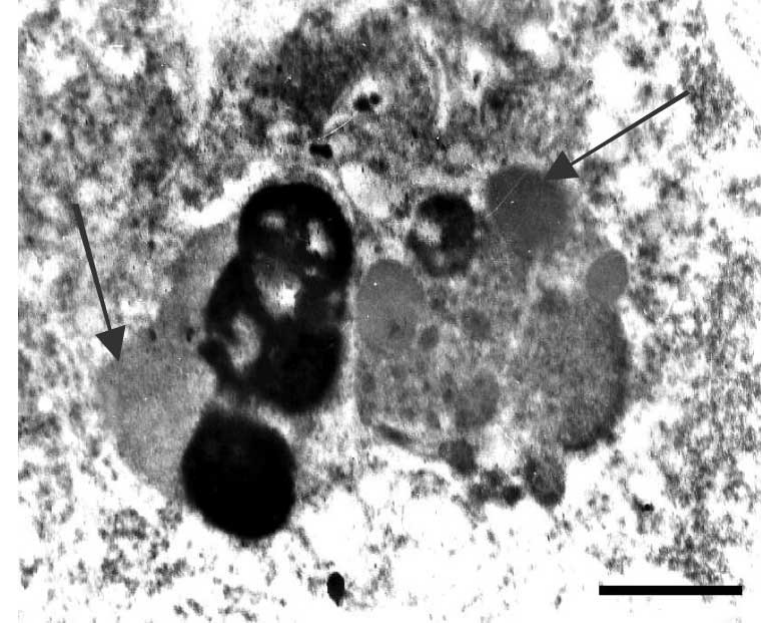

Fig. 2. Ultrathin section of the fragments of liver. Intracytoplasmic viral inclusion bodies (arrow). Bar: 800nm.

Similar viral morphology was also described in other species such as geese (Soike et al., 1999), pigeons (Woods et al., 1993; Gough \& Drury, 1996; Raidal \& Riddoch, 1997), ostrichs (Els \& Josling) and cockatoos (Sanada et al.).

When using resin embedding technique, the analysis of ultrathin sections of liver fragments of 20 $(100 \%)$ canaries showed the presence of viral intracytoplasmic inclusions, containing viral particles $10-14 \mathrm{~nm}$ of diameter with loose arrangements or paracrystalline arrays.

Other ultrastructural studies showed the presence of circovirus in the small intestine of canaries (Rampin et al.), bursa of Fabricius of pigeons (Woods et al., 1993; Shivaprasad et al., 1994, 2004), geese (Soike et al., 1999) gull (Twentyman et al., 1999) and in the skin of Psittacines (Latimer et al., 1991; Sanada et al.; Kiatipattanasakul-Banlunara et al.).

In the analyzed literature there are no ultrastructural citations on the presence of this virus in the liver of canaries.

The circovirus predilection for certain organs in avian species is not well established (Todd et al., 2001). Histopathology tests had shown intracytoplasmic and intranuclear inclusion bodies in skin lesions and digestive tract (Latimer et al.; Todd, 2000).

Some authors suggest that the immunosuppressive action of the virus is commonly associated with pathological changes in lymphoid organs, mainly 
bursa of Fabricius and spleen being responsible for potentially fatal disease (Todd, 2000; Phenix et al.).

In this study, 101 (31.66\%) out of 317 Saffron finch found dead in the Wild Animal Recovery Center of the Tietê Ecological Park or showing apathy, ruffled feathers and sudden death without any other apparent symptoms or classic sign reported in the literature, such as enteritis, sinusitis, rhinitis, tracheitis, bronchopneumonia, myocarditis, nephritis, splenitis, dyspnea, anorexia, lethargy, depression, dullness, feather disorder (Phenix et al.; Rampin et al.)

There are no records of occurrence of circovirus in commercial breeds of chickens or turkeys, but these viruses have already been found in ducks, geese and canaries from commercial breeds. Moreover, little is known about the clinical pathologic and economic impact of the disease (Hatterman et al., 2003; Soike et al., 1999, 2004).

The transmission electron microscopy, by means of the negative staining and resin embedding techniques, is an important instrument to detect circovirus particles (Woods $\&$ Latimer). The definite diagnosis of this infection requires observation of characteristic particles (Latimer et al.; Ritchie \& Latimer, 1995).

This is the first report on the presence of circovirus in Saffron finch (Sicalis flaveola spp.).

CATROXO, M. H. B.; MARTinS, A. M .C. R. P. F.; MELO, N. A. ; MILANELO, L. ; PETRELLA, S.; FITORRA, L. S. \& PETRI, B.S.S. Identificación ultrastructural de circovirus en el hígado de canarios venezolanos (Sicalis flaveola spp.). Int. J. Morphol., 29(2):537-542, 2011.

RESUMEN: Circovirus son agentes virales que causan enfermedad en las aves. Los principales síntomas clínicos de la enfermedad son la inmunosupresión y desórdenes en las plumas de aves jóvenes. En los recién nacidos la enfermedad se conoce como "punto negro" y se caracteriza por distensión abdominal, congestión hepatobiliar y falla en el desarrollo. También se han observado en las aves adultas infectadas, otros síntomas y signos clínicos, tales como la enteritis, sinusitis, rinitis, traqueitis, bronconeumonía, miocarditis, nefritis, esplenitis, disnea, anorexia, depresión llevando también a alta mortalidad. En abril de 2008, durante una comercialización ilegal, fueron confiscados 317 canarios venezolanos, siendo llevados al Centro de Rehabilitación de Animales Silvestres del Parque Ecológico de Tietê. Posteriormente, 101 (31,66\%) aves murieron y entre éstas fueron seleccionadas 20 y enviadas al Laboratorio de Microscopía Electrónica, Instituto Biológico de São Paulo, para identificar el posible agente etiológico. Después de la necropsia, fragmentos de pulmón, hígado e intestino delgado se procesaron mediante las técnicas de tinción negativa y de inclusión en resina. A través de microscopía electrónica de transmisión, la técnica de tinción negativa permitió visualizar en las 20 muestras (100\%) de suspensión del hígado, un gran número de partículas con morfología similar al circovirus, esférico, sin envoltura, isométrico, que se caracteriza como "completa" y "vacío", que miden entre 17 y 20 nm de diámetro. Mediante la técnica de cuerpos de inclusión en resina se observó en el $100 \%$ de las muestras de suspensión de hígado, cuerpos de inclusión virales intracitoplasmáticos, redondeadas u ovales, con partículas de virus dispuestos en matrices paracristalinas o sueltas en los cortes ultrafinos. Este es el primer reporte de la presencia de circovirus en canarios Venezolanos (Sicalis flaveola spp.).

PALABRAS CLAVE: Circovirus de Aves; Canarios; Sicalis flaveola spp.

\section{REFERENCES}

Allan, G. M. \& Ellis, J. A. Porcine circoviruses: a review. J. Vet. Diagn. Invest., 12(1):3-14, 2000.

Bassami, M. R.; Berryman, D.; Wilcox, G. E. \& Raidal, S. R. Psittacine beak and feather disease virus nucleotide sequence analysis and its relationship to porcine circovirus, plant circoviruses, and chicken anaemia virus. Virology, 249(2):453-9, 1998.

Brenner, S. \& Horne, R.W. A negative staining method for high resolution electron microscopy of viruses. Biochim. Biophys. Acta, 34:103-10, 1959.

Els, H. J. \& Josling, D. Viruses and virus-like particles identified in ostrich gut contents. J. S. Afr. Vet. Assoc., 69(3):74-80, 1998.

Goldsmith, T. L. Documentation of passerine circoviral infection. In: Proceedings of the Annual Conference of the Association of Avian Veterinarians, Philadelphia, PA, USA, 1995. pp.349-50.

Gonzáles-Santander, R. Técnicas de microscopia eletrônica en biología. Madrid, Aguilar, 1969. pp.666.

Gough, R. E. \& Drury, S. E. Circovirus-like particles in the bursae of young racing pigeons. Vet. Rec., 138(7):167, 1996. 
Guercio, A.; Zancope, G.; Di Marco, V.; Brasola, V. \& Capua, I. Infezione da circovirus-like associata ad elevata mortalita in canarini italiani (Gibber italicus). Selezione Veterinaria, 8-9:791-4, 2000.

Halami, M. Y.; Nieper, H.; Müller, H. \& Johne, R. Detection of a novel circovirus in mute swans (Cygnus olor) by using nested broad-spectrum PCR. Virus Res., 132(12):208-12, 2008.

Hattermann, K.; Schmitt, C.; Soike, D. \& Mankertz, A. Cloning and sequencing of Duck circovirus (DuCV). Arch. Virol., 148(12):2471-80, 2003.

Hayat, M. A. \& Miller, S. E. Negative Staining. New York, McGraw-Hill,1990. pp.253.

Johne, R.; Fernández-de-Luco, D.; Höfle, U. \& Müller, H. Genome of a novel circovirus of starlings, amplified by multiply primed rolling-circle amplification. J. Gen. Virol., 87(Pt 5):1189-95, 2006.

Kiatipattanasakul-Banlunara, W.; Tantileartcharoen, R.; Katayama, K.; Suzuki, K.; Lekdumrogsak, T.; Nakayama, H. \& Doi, K. Psittacine beak and feather disease in three captive sulphur-crested cockatoos (Cacatua galerita) in Thailand. J. Vet. Med. Sci., 64(6):527-9, 2002.

Latimer, K. S.; Rakich, P. M.; Steffens, W. L.; Kircher, I. M.; Ritchie, B. W.; Niagro, F. D. \& Lukert, P. D. A novel DNA virus associated with feather inclusions in psittacine beak and feather disease. Vet. Pathol., 28(4):300-4, 1991.

Luft, J. H. Improvements in epoxy resin embedding methods. J. Biophys. Biochem. Cytol., 9:409-14, 1961.

Madeley, C. R. Origins of electron microscopy and viral diagnosis. J. Clin. Pathol., 50(6):454-6, 1997.

Niagro, F. D.; Forsthoefel, A. N.; Lawther, R. P.; Kamalanathan, L.; Ritchie, B. W.; Latimer, K. S. \& Lukert, P. D. Beak and feather disease virus and porcine circovirus genomes: intermediates between the geminiviruses and plant circoviruses. Arch. Virol., 143(9):1723-44, 1998.

Phenix, K. V.; Weston, J. H.; Ypelaar, I.; Lavazza, A.; Smyth, J. A.; Todd, D.; Wilcox, G. E. \& Raidal, S. R. Nucleotide sequence analysis of a novel circovirus of canaries and its relationship to other members of the genus Circovirus of the family Circoviridae. J. Gen. Virol., 82(Pt 11):2805-9, 2001.
Raidal, S. R. \& Riddoch, P. A. A feather disease in Senegal doves (Streptopelia senegalensis) morphologically similar to psittacine beak and feather disease. Avian Pathol., 26(4):829-36, 1997.

Rampin, T.; Manarolla, G.; Pisoni, G.; Recordati, C. \& Sironi, $\mathrm{G}$. Circovirus inclusion bodies in intestinal muscle cells of a canary. Avian Pathol., 35(4):277-9, 2006.

Raue, R.; Schmidt, V.; Freick, M.; Reinhardt, B.; Johne, R.; Kamphausen, L.; Kaleta, E. F.; Müller, H. \& Krautwald-Junghanns, M. E.A disease complex associated with pigeon circovirus infection, young pigeon disease syndrome. Avian Pathol., 34(5):418$25,2005$.

Reynolds, E. S. The use of lead citrate at high $\mathrm{pH}$ as an electron-opaque stain in electron microscopy. J. Cell Biol., 17:208-12, 1963.

Ritchie, B. W.; Niagro, F. D.; Latimer, K. S.; Steffens, W. L.; Pesti, D.; Ancona, J. \& Lukert, P. D. Routes and prevalence of shedding of psittacine beak and feather disease virus. Am. J. Vet. Res., 52(11):1804-9, 1991.

Ritchie, B.W. \& Latimer, K.S. Beak and feather disease virus. In: Bonagura J. D.; Kirk, R.W.; Osborne, C.A. Kirk's Current Veterinary Therapy XII: Small Animal Practice. Philadelphia, WB Saunders Co., 1995. pp. 1288-94.

Sanada, Y.; Sanada, N. \& Kubo, M. Electron microscopical observations of psittacine beak and feather disease in an Umbrella cockatoo (Cacatua alba). J. Vet. Med. Sci., 61(9):1063-5, 1999.

Shivaprasad, H. L.; Chin, R. P.; Jeffrey, J. S.; Latimer, K. S.; Nordhausen, R. W.; Niagro, F. D. \& Campagnoli, R. P. Particles resembling circovirus in the bursa of Fabricius of pigeons. Avian Dis., 38(3):635-41, 1994.

Shivaprasad, H. L.; Hill, D.; Todd, D. \& Smyth, J. A. Circovirus infection in a Gouldian finch (Chloebia gouldiae). Avian Pathol., 33(5):525-9, 2004.

Smyth, J. A.; Todd, D.; Scott, A.; Beckett, A.; Twentyman, C. M.; Bröjer, C.; Uhlhorn, H. \& Gavier-Widen, D. Identification of circovirus infection in three species of gull. Vet. Rec., 159(7):212-4, 2006.

Soike, D.; Albrecht, K.; Hattermann, K.; Schmitt, C. \& Mankertz, A. Novel circovirus in mulard ducks with developmental and feathering disorders. Vet. Rec., 154(25):792-3, 2004. 
Soike, D.; Kohler, B. \& Albrecht, K. A circovirus-like infection of geese related to a runting syndrome. Avian Pathol., 28:199-202, 1999.

Stewart, M. E.; Perry, R. \& Raidal, S. R. Identification of a novel circovirus in Australian ravens (Corvus coronoides) with feather disease. Avian Pathol., 35(2):86-92, 2006.

Todd, D.; Niagro, F. D.; Ritchie, B. W.; Curran, W.; Allan, G. M.; Lukert, P. D.; Latimer, K. S.; Steffens, W. L. 3rd. $\&$ McNulty, M. S. Comparison of three animal viruses with circular single-stranded DNA genomes. Arch. Virol., 117(1-2):129-35, 1991.

Todd, D. Circoviruses: immunosuppressive threats to avian species: a review. Avian Pathol., 29(5):373-94, 2000.

Todd, D. Avian circovirus diseases: lessons for the study of PMWS. Vet. Microbiol., 98(2):169-74, 2004.

Todd, D.; Scott, A. N.; Fringuelli, E.; Shivraprasad, H. L.; Gavier-Widen, D. \& Smyth, J. A. Molecular characterization of novel circoviruses from finch and gull. Avian Pathol., 36(1):75-81, 2007.

Todd, D.; Bendinelli, M.; Biagini, P.; Hino, S.; Mankertz, A.; Mishiro, S.; Niel, C.; Okamoto, H.; Raidal, S.; Ritchie, B.W. \& Teo, G. C. Circoviridae. In: Fauquet, C.M.; Mayo, M. A.; Maniloff, J.; Desselberger, U. \& Ball, L. A. Virus Taxonomy, VIIIth Report of the International Committee for the Taxonomy of Viruses, London, Elsevier/ Academic Press, 2005. pp.327-34.

Todd, D.; Weston, J. H.; Soike, D. \& Smyth, J. A. Genome sequence determinations and analyses of novel circoviruses from goose and pigeon. Virology, 286(2):354-62, 2001.

Twentyman, C. M.; Alley, M. R.; Meers, J.; Cooke, M. M. \& Duignan, P. J. Circovirus-like infection in aSouthern black-backed gull (Larus dominicanus). Avian Pathol., 28:513-6, 1999.

Watson, M. L. Staining of tissue sections for electron microscopy with heavy metals. J. Biophys. Biochem. Cytol., 4(4):475-8, 1958.

Woods, L. W.; Latimer, K. S.; Barr, B. C.; Niagro, F. D.; Campagnoli, R. P.; Nordhausen, R. W. \& Castro, A. E. Circovirus-like infection in a pigeon. J. Vet. Diagn. Invest., 5(4):609-12, 1993.
Woods, L. W. \& Latimer, K. S. Circovirus infection of nonpsittacine birds. J. Avian Med. Surg., 14:154-63, 2000.

Correspondence to:

Prof. Dr. Marcia Catroxo

Electron Microscopy Laboratory

Research and Development Center in Animal Health

Biological Institute of São Paulo

Av. Conselheiro Rodrigues Alves, 1252

CEP 04014-002

Vila Mariana

São Paulo, SP

BRAZIL

Email: catroxo@biologico

Received: 08-01-2011

Accepted: 17-03-2011 